\title{
War or Peace Journalism? Study of Media Coverage by Russian Media Outlets of the Trade War Between China and the USA
}

\author{
Viktor Tuzov \\ ORCID: 0000-0003-3137-4761 \\ City University of Hong Kong, Hong Kong SAR
}

\begin{abstract}
In recent years, the trade war between China and USA became one of the most important crises not only in global economic relations, but also in the international political agenda. The trade war between the world's major powers also involved the core countries from differing regions, due to the significance of the trading streams between China and the USA. Therefore, Russia as one of the core countries was also affected by this trade war and attempted to develop own policy and economic relations towards the two sides. The current research is devoted to analysing the Russian media coverage of the trade war between China and USA based on content analysis and the implication of structural differences existing in the current Russian media system into war and peace journalism paradigms.
\end{abstract}

KEYWORDS: Trade War, Crisis communication, Media frames, Peace and war journalism, Russian media.

\section{INTRODUCTION}

The trade war between USA and China became a significant point of the modern global community due to the political and economic importance not only segmentally for the two sides of the trade war, but also for all countries in the world, because of the overall economic, political and technological power of two countries. For this reason, the trade war become a part of the contemporary superpower confrontation as the USA is the only superpower in the world, which could dominate the global agenda.

In this case, core regional countries across the world struggle to demonstrate their interests and influence the global trade war on the supranational level. Russia claims to be a key player in the European region and even a global superpower 
and is involved in the trade war as an observer with its own interests and formed political and economic attitudes towards the two sides (Troush, 2014).

In the context of journalism's war and peace frames, the research focused on the specifics of the current Russian media system that consists of two different types of media financing: federal and commercial. Consequently, Russia's media outlets are covering the trade war in ways dependent on their editorial policies, which closely connect with their source of income. Moreover, the media outlets have been divided according to their platforms: traditional or new media, which have been also implemented into research to analyze the war and peace frames in more comprehensive way.

The current research also sought to discover the Russian media's political orientation and attitude towards the two sides of the trade war. The results of the research are based on qualitative content analysis, which involves a coding process.

\section{LITERATURE REVIEW \& THEORETICAL FRAMEWORK}

\section{FRAMING THEORY IN TERMS OF CONFLICT SITUATION}

Previous research on the framing theory in conflict situations claims that the production of foreign news by national outlets is usually influenced by the country's relations with foreign countries, state or editorial ideology, national foreign policy and economic relations. The importance of these factors has been unveiled during the coverage of political, but also economic relations between countries, especially in the competing regions. In one of those cases, the research highlighted the difference in the coverage of Korea and Japan in terms of their economic development and relations with the USA during the 1990s (Park, 2003). Despite the positive political and social relations between both countries, the USA's media have covered Japan with negative frames due to the ongoing economic disagreements, while depicting Korea's economic growth in positive terms because of the correlation with the USA's economic interests in the Asian region (Park, 2003).

This shows that the frames gain extra importance during the coverage of conflicts and crises. The frames become the way of covering conflict situations by shaping reality and its subsequent development related to the position of the media organization doing the coverage. In this way, the framing interacts with the conflicts in terms of discourse and development of the agenda. So, each point of conflict undergoes the process of identifying and explaining the events based on geopolitical and economic proximity and the historical background of the conflict and the involved countries (Ahmed et al., 2018). 


\section{THE RUSSIAN MASS MEDIA BACKGROUND}

Russia according to a global rating of media freedom (Freedom House, 2016), has 6.5 points out of 7 ( 7 is the lowest level of democratic progress). This rating refers to states with strong media limitations, which can affect the overall freedom of speech. In this case, most research considers the Russian media system as mainly dependent on state control, and thus classify Russian mass media into three categories: (i) fully and officially owned by the government, (ii) indirectly controlled by the government (through the media corporations owned by the pro-governmental companies, through the federal subsidies or even by promotion of private owners with financial support) and (iii) commercial media outlets with an almost independent position. However, the number of media outlets from the last category has declined due to the constant pressure that the state applies (Gehlbach \& Sonin, 2014).

The information policy of Russian media companies varies according to the funding type. There are two main types of media companies in the Russian media system: government funded (henceforth federal) and commercial. The first type - federal - has a long tradition of media framing. Due to federal financial support, these media organizations create the calm and balanced content covering the domestic events and more emotionally unbalanced and arrogant content covering the international news. Moreover, in both cases, federal media focus selectively on events and personalities favorable for coverage, producing news corresponding to current political and economic policies of state leadership (Lozovskiy, 2011).

Analyzing the media framing process of Russian commercial media, it is clear that the media policy of such organizations is mainly based on economic efficiency and profits from advertising and issue sales. This type of mass media acts according to the principles of the free market economy, so the main purpose of Russian commercial media outlets is mostly bound up with attracting an audience and gaining more profits. Therefore, media framing is bound up with sensationalism and more uninhibited content, especially in case of domestic news coverage, however the coverage of international news events is still mainly correlated to the position of the government (Kravets, 2016). Despite this trend, the commercial new (digital) media are more inclined to cover overseas events with the use of news vectors, which can be distinct from or even oppose the official position of the government. That is the reason the analysis of media frames adopted by the types of media outlets became an important part of the theoretical framework (Kirshin, 2012).

The emergence and rapid growth of the new (digital) media outlets reflects the changes in the Russian media market and the correlation of new media development with the existence of traditional media companies (print media). The expansion of the new media in Russia's media system corresponds to the 
global trend towards the digital. However, the historically based significance of print media as the only reliable source of information is more related to the government and its credibility among the readers (especially in the regional media market). This indicates the importance of this type of media during the process of media agenda analysis. Moreover, due to the less degree of control of the new media sphere and the strive to publish sensationalism, the disinformation and exaggeration of facts has become the negative specifics of the new media overall image. That is why it also affects the way of reporting performed by this type of outlet. Press events like the Arab Spring, the Crimea-Ukrainian crisis etc. have revealed the distinctive differences in the coverage of events by traditional and new media outlets. There is also the strive to achieve the negativistic pattern of media information and the ubiquitous violation of the ethical principles caused by digital media companies (Nazmetdinova \& Lebedeva, 2018).

\section{THE WAR AND PEACE JOURNALISM}

The theoretical framework of the research is based on the contemporary scientific literature about the war and peace journalism. This phenomenon existed from the beginning of journalistic activity and was as equally significant in the past as it is in the development of modern journalism, which is overcoming various political, economic and social challenges. Therefore, the coverage of conflicting issues implements the war and peace frames into the media content, which become a competing constituent of the articles (Coombs, 1999). In this case, war journalism is focused on propaganda, elites, and the dominant point of view of conflict and violence, so it is bound up more with emotional and visible effects of content. However, the peace journalism approach is focused more on the moral, social justice, social participation, values and points of view of different social and political groups (Galtung, 1998).

Pairs of opposing models developed by Galtung (1998) have been subsequently supported by detailed classification based on the polarization of concepts: people/ elites, balanced/agitated, truth/propaganda, solutions/differences, convergence/ prejudice. Therefore, when war journalism focuses on the differences of the two sides and shades them in black and white the probable ways of conflict resolution are covered with the implication of a violent background. Consequently, peaceful solutions are hidden and even neglected. On the other hand, peace journalism operates with approved and accurate information to de-escalate the crisis and show both the advantages and disadvantages of each side of the conflict. This strategy is aimed to reduce the gap between the conflicting sides (Galtung, 1998).

Therefore, the current research has implemented the following categories based on the type of research project. Due to the analysis of the trade war, the categories of "“Elite-oriented" and "people-oriented", "Partisan" and "non-partisan", "Dichotomizes good and bad, victims and villains" and "Avoid labeling 
of good and bad guys" and "Balanced and agitated" (all the emotional level of the articles) are represented as the most effective and comprehensive way to analyze the trade war without military interventions. Thus, the criteria for category selection are based on the type of crisis, which is not related to open conflict with the implication of aggressive propaganda resources. That is why the chosen categories could classify the media texts in a more applicable and analytical way. In this vein, the classifications mentioned above can be more correlated with the economic orientation of a substantial number of articles identified during the data analysis (Nicolas-Gavilan, 2018).

\section{THE POLITICAL AND ECONOMIC BACKGROUND OF TRADE WAR}

The trade war between China and USA was an issue with a prolonged background based on the factors of China's economic growth and the striving for leadership in the sphere of new technologies. For this reason, the growing confrontation between the countries started at the beginning of the 2000s. The most significant point in this process was the intensification of China's business activity in US and EU markets. This caused suspicions and concerns about how China's economic growth had turned into the new danger for some of America's business and political authorities (Financial Times, 2005). Analyzing this process, Western scholars have even used the term "yellow danger" or "yellow peril", which refers to the period of the late 19th century when Western countries considered China as a competitor against the stability of overseas colonies in the Asian region (Zeng Ka, 2004).

According to the political and increasing economic confrontation between China and USA, Russia is a bystander that can also influence the mutual interrelations between the other two countries. Scholars emphasize that the Russian foreign policy position can be examined as being a close partner and political ally of China (Balakin, 2017). However, it has been also noted (Davydov, 2017) that the partnership between Russia and China has been influenced by a range of factors. These are primarily the underlying weakness of the economy as well as the shrinking horizons of the country's foreign policy and military power. Of secondary importance are the ability of Russia's authorities to fulfill independent policies based on values close to China's foreign policy and the importance of Russia as a resource-based partner for that country. Last but not least are the ideological and historical backgrounds that underpin their relationship with each other, which would promote a pro-Chinese position among Russian officials. So, based on this analysis researchers have been trying to predict Russia's position during the probable political or economic conflicts between China and the USA (Vinogradov, 2013). 


\section{RESEARCH QUESTIONS}

The formulated research questions (RQs) revolve around a 'dominant frame' of either war or peace journalism: (RQ1) Does the dominant frame of the trade war coverage differ between Russia's state-owned media and its commercial counterpart? (RQ2) Does the dominant frame of the trade war coverage differ between the Russia's traditional (print and analog broadcast media) and the new media (digital)? (RQ3) Does the dominant frame change during study period?

The research project aimed to discover the specifics of coverage of the trade war between China and the USA using framing theory to disclose the overall image of the tensions among Russia's media, as well as the war and peace journalism paradigm to identify the dominant frames on the trade war coverage among the two types of media.

\section{METHODOLOGY}

The research was conducted using framing theory by implementing the war and peace journalism paradigm, as well as the media image of USA and China constructed by Russia's media outlets. Furthermore, the research time framework was restricted by the key chronological events: (1) the first period (pre-trade war): from Trump's coming to power on January 20th, 2017 till the beginning of trade war's active phase on January 22nd, 2018; (2) the second period (the active phase of the trade war): from the implementation of first trade tariffs (January 22nd, 2018) to the cessation of the study's data collection (September 26th, 2019).

The research sample consisted of trade war related articles obtained from selected media outlets. The research focused on the content in Russia's national newspapers in both printed and electronic versions, as well as the new media outlets (on the Internet). The newspapers and internet portals were selected according to their popularity among the audience as well as their media financing type (federal or commercial) and platform (traditional or new media). In order to avoid both bias and doubt in the research's validity, one media outlet for each category was selected: Rossiyskaya gazeta is a federal funded traditional media outlet, Ria Novosti is a federal funded new media digital outlet, Kommersant is a commercial traditional media outlet and Lenta.ru is a commercial new media digital outlet.

Rossiyskaya gazeta is a daily newspaper providing coverage of government activities: federal laws, legislative acts and presidential orders. The newspaper officially portrays itself as the printed organ of the Government of Russia.

Ria Novosti is one of the most influential Russian news agencies with headquarters in Moscow. Ria Novosti covers all sides of political, economic and social 
news from Russia and across the world. This analytical media outlet is an official source of information for the Russian President's Administration, the Government of Russia, the ministries and other federal institutions across the country.

Kommersant is one of the leading commercial daily newspapers in Russia and focuses on the coverage of domestic and international business, as well as political events. The newspaper is related to the liberal broadsheets with the main audience consisting of business and political elites, representatives of business enterprises, as well as the academic and cultural elites of Russia.

Lenta.ru is an online newspaper, which covers domestic and international news. It was one of the most quoted media outlets in Russia during the first decade of the 21st century. Lenta.ru achieved 5th place in the rankings of European online newspapers in 2013 (Comscore, 2013).

According to the background information about the selected media outlets, the sample adequately represents Russia's media landscape in terms of international news coverage and the Sino-American trade war analysis. The media selection matched the media ratings compiled by Medialogy, Russia's leading company in monitoring the Russian media field, which also has the largest news media database in the country. Medialogy ranked Kommersant and Rossiyskaya gazeta as the leading National Newspapers in 2017. At the same time, for the ratings in the Internet Resources of 2017, Medialogy awarded top ranking to Lenta.ru and Ria Novosti (Medialogy, 2017). The composite index used by the company to form the statistics has been based on the criteria of citation index, media importance and audience structure of each media outlet. Moreover, an additional factor for selecting the media outlets was the availability of public access to the articles' archives in order to subsequently identify the articles related to the trade war.

The procedures of the articles' selection and collection was done manually using the websites' built-in search tools to find content related to the trade war in the media websites archives. Due to the broad nature of the topic, the articles were predominantly in seven categories: "Politics", "In the world", "Economics", "Society", "Business" and "Finances", as well as "Russia", which also contained some of the articles related to the trade war (in terms of consequences for the Russian economy). Prior to the analysis of articles, the publications were scrutinized for keywords, such as "trade war" and "trade conflict", with the selection of content directly connected with the trade war between China and USA. The sample consists of 33 articles from the first period of research and 398 articles from the second period. 


\section{CODING}

\section{THE BASIC CODING CATEGORIES}

The first part of coding process involved developing the schema of categories aimed at depicting the main trends of the trade war coverage in the Russian media landscape. It included following variables: (1) The name of the media outlet; (2) The financing type of media organization: federal, commercial; (3) The media platform: traditional, new media; (4) The date of publication;

(5) The number of articles; (6) The type of content: political, economic, social;

(7) The length of the articles; (8) The attitude to USA: positive, negative, neutral; (9) The attitude to China: positive, negative, neutral; (10) The keyword; (11) The keyword frequency.

Intercoder reliability was checked, tested and validated by a researcher familiar with the use of content analysis methodology. In this case, a Russian speaking master's student of Shanghai International Studies University was tasked with analyzing the content of 86 randomly selected articles using the same coding sheet. Prior to the testing, there was instruction on the research focus and theory. Consequently, two further rounds of training were conducted, each with 20 randomly selected articles, in order to clarify any points of disagreement and to increase agreement between coders. The 11 categories of analyses did not change.

The procedure for the intercoder reliability test was based on Cohen's kappa coefficient and conducted using SPSS statistics software. The analysis of content, accordingly to the selected categories, identified the insignificant differentiation in the results. In this vein, the test reflects a solid agreement between the two coders in following six specific categories: (i) Attitude to China, $\kappa=.799$ (95\% CI, .675 to .922), $p<.001$; (ii) Attitude to USA, $\kappa=.815$ (95\% CI, .701 to .928), $p<.001$; (iii) Agitated/Balanced, $\kappa=.714$ (95\% CI, .594 to .833), $p<.001$; (iv) Partisan/ Non-partisan, $\kappa=.702$ (95\% CI, .547 to .856), $p<.001$; (v) Elite-oriented/Peopleoriented, $\kappa=.784$ (95\% CI, .650 to .917), $p<.001$; (vi) Dichotomizes good and bad, victims and villains/Avoid labeling of good and bad guys, $\kappa=.755$ (95\% CI, .613 to .896), $p<.001$.

After the checking the aggregate of the sample, it became clear that the 11 main and 6 specific categories relating to the war and peace journalism could display the same tendencies identified during the main research process. Moreover, the reliability test approved the indicators for categorization of articles based on the Galtung's (1998) principles. Therefore, the current research methodology, as well as the coding sheet categorization are reliable and could be replicable for future studies. 


\section{THE PEACE AND WAR CATEGORIZATION}

The four binary categories of article content that are based on Galtung's (1998) approach were used to conduct the current research: Elite-oriented and people-oriented focus on elites and leaders or the general public as the main actors with the following descriptive indicators: the depiction of difficulties the general public experience during the trade war, the outcomes of the trade war on the everyday life in the affected geographical zone, and on the political and economic establishment of the country, as well as on celebrities. Partisan and non-partisan focus on content bias: supporting of one side of the conflict or neutral where the indicator is the presence of emotionally strong words describing one side of the trade war. Dichotomizes good and bad, victims and villains and Avoid labeling good and bad actors where a descriptive indicator indicates the culprits, victims and peacemakers of the trade war focusing on a description of the trade war's process without seeking possible resolutions. Agitated and balanced focus on the emotional level of the articles, with the results presented in numerical form, according to a scale of 1 (balanced) to 5 (agitated). An emotive specific indicator was also used. This involved identifying emotive words or phrases describing the trade war and marking a scale based on the quantity of emotive words: 1 - less than 5 words, 2 - from 5 to 10 words, 3 - from 11 to 15 words, 4 - from 16 up 25 words, and 5 - more than 25 words.

The attitude of each article was determined by the identification of lexical indicators in the text, which disclosed a specific set of attitudinal parameters positive, negative and neutral - shown towards the research objects. 


\section{FINDINGS}

The aggregate sample of articles $(\mathrm{N}=431)$ was split between the two data collection periods; 1st period $(n=33)$ and 2 nd period $(n=398)$. Table 1 presents the most productive of the sample media by order of frequency of article publications.

Table 1. Frequency of article production by the selected Russian media outlets concerning the Sino-American trade war during the two data collection periods.

\begin{tabular}{|c|c|c|}
\hline 1st Data Collection Period & Media Outlet & Article Production $(\mathrm{N}=33)$ \\
\hline \multirow{4}{*}{$20.01 .2017-22.01 .2018$} & Rossiyskaya gazeta & $\mathrm{n}=6$ \\
\hline & Ria Novosti & $\mathrm{n}=12$ \\
\hline & Kommersant & $\mathrm{n}=11$ \\
\hline & Lenta.ru & $\mathrm{n}=4$ \\
\hline 2nd Data Collection Period & Media Outlet & Article Production $(\mathrm{N}=398)$ \\
\hline \multirow[t]{4}{*}{$22.01 .2018-26.09 .2019$} & Rossiyskaya gazeta & $\mathrm{n}=96$ \\
\hline & Ria Novosti & $\mathrm{n}=100$ \\
\hline & Kommersant & $\mathrm{n}=102$ \\
\hline & Lenta.ru & $\mathrm{n}=100$ \\
\hline
\end{tabular}

Source: Author's own research

\section{THE OVERALL TREND OF TRADE WAR NEWS REPORTING AMONG RUSSIAN MEDIA}

Due to the research time frame, the data analysis was split into two parts for better understanding of changes that occurred in the media coverage of the trade war during the pre-trade war period and its active phase. So, during the first period the federal media expressed the attitude towards the two sides of the trade war in a more neutral way than is prevalent for both countries. Compared to federal media, commercial media outlets have positioned themselves in a more agitated way, with a negative image dominant for the USA, and a neutral for China. In this case, the comparison between the traditional and new media depicted clear tendencies: the newspapers displayed a neutral attitude towards the two sides in the trade war. However, the new media covered the trade war in more biased way using war frames (Table 2). 
Table 2. Russian media's attitudes towards the Sino-American trade war's two sides. First period (20.01.2017-22.01.2018)

\begin{tabular}{|c|c|c|c|c|c|c|c|c|}
\hline & \multicolumn{2}{|c|}{$\begin{array}{c}\text { Federal }(\mathrm{N}=18) \\
\text { Rossiyskaya } \\
\text { gazeta }(\mathrm{n}=6) \\
\text { Ria Novosti }(\mathrm{n}=12)\end{array}$} & \multicolumn{2}{|c|}{$\begin{array}{l}\text { Commercial }(N=15) \\
\text { Kommersant }(n=11) \\
\text { Lenta.ru }(n=4)\end{array}$} & \multicolumn{2}{|c|}{$\begin{array}{c}\text { Traditional }(\mathrm{N}=17) \\
\text { Rossiyskaya } \\
\text { gazeta }(\mathrm{n}=6) \\
\text { Kommersant }(\mathrm{n}=11)\end{array}$} & \multicolumn{2}{|c|}{$\begin{array}{c}\text { New media }(N=16) \\
\text { Ria Novosti }(n=12) \\
\text { Lenta.ru }(n=4)\end{array}$} \\
\hline & USA & China & USA & China & USA & China & USA & China \\
\hline Negative & $\begin{array}{c}6 \\
(33.3 \%)\end{array}$ & 0 & $\begin{array}{c}7 \\
(46.6 \%)\end{array}$ & $\begin{array}{c}4 \\
(26.7 \%)\end{array}$ & $\begin{array}{c}6 \\
(35.3 \%)\end{array}$ & $\begin{array}{c}2 \\
(11.8 \%)\end{array}$ & $\begin{array}{c}7 \\
(43.75 \%)\end{array}$ & $\begin{array}{c}2 \\
(12.5 \%)\end{array}$ \\
\hline Neutral & $12(66.7 \%)$ & $\begin{array}{c}12 \\
(66.7 \%)\end{array}$ & $\begin{array}{c}4 \\
(26.7 \%)\end{array}$ & $\begin{array}{c}7 \\
(46.6 \%)\end{array}$ & $9(52.9 \%)$ & $\begin{array}{c}11 \\
(64.7 \%)\end{array}$ & $\begin{array}{c}7 \\
(43.75 \%)\end{array}$ & $\begin{array}{c}8 \\
(50 \%)\end{array}$ \\
\hline Positive & 0 & $\begin{array}{c}6 \\
(33.3 \%)\end{array}$ & $\begin{array}{c}4 \\
(26.7 \%)\end{array}$ & $\begin{array}{c}4 \\
(26.7 \%)\end{array}$ & $\begin{array}{c}2 \\
(11.8 \%)\end{array}$ & $\begin{array}{c}4 \\
(23.5 \%)\end{array}$ & $\begin{array}{c}2 \\
(12.5 \%)\end{array}$ & $\begin{array}{c}6 \\
(37.5 \%)\end{array}$ \\
\hline
\end{tabular}

Source: Author's own research

In the second period (see Table 3), the main attitude of federal media remained neutral towards USA, and both neutral and positive towards China. The main attitude of the commercial media changed direction, but still looked similar: USA - neutral with the negative shades; China - predominantly positive. At the same time, the traditional media coverage of the trade war kept a similar tendency as during the active phase. However, the new media focus did change with the representation of USA becoming more negative compared to the pre-trade war period. This finding corresponds to the main trend of Russian media outlets that started to use aggressive rhetoric against the USA due to the intensification of the crisis and the negative background of the countries' relations.

Table 3. Russian media's attitudes towards the Sino-American trade war's two sides. Second period (22.01.2018-26.09.2019)

\begin{tabular}{|c|c|c|c|c|c|c|c|c|}
\hline & \multicolumn{2}{|c|}{$\begin{array}{c}\text { Federal }(\mathrm{N}=196) \\
\text { Rossiyskaya gazeta } \\
(\mathrm{n}=96) \\
\text { Ria Novosti }(\mathrm{n}=100)\end{array}$} & \multicolumn{2}{|c|}{$\begin{array}{l}\text { Commercial }(\mathrm{N}=202) \\
\text { Kommersant }(n=102) \\
\text { Lenta.ru }(n=100)\end{array}$} & \multicolumn{2}{|c|}{$\begin{array}{c}\text { Traditional }(\mathrm{N}=198) \\
\text { Rossiyskaya } \\
\text { gazeta }(\mathrm{n}=96) \\
\text { Kommersant }(\mathrm{n}=102)\end{array}$} & \multicolumn{2}{|c|}{$\begin{array}{c}\text { New media }(N=200) \\
\text { Ria Novosti }(n=100) \\
\text { Lenta.ru }(n=100)\end{array}$} \\
\hline & USA & China & USA & China & USA & China & USA & China \\
\hline Negative & $\begin{array}{c}61 \\
(31.2 \%)\end{array}$ & $\begin{array}{c}1 \\
(0.6 \%)\end{array}$ & $\begin{array}{c}73 \\
(36.1 \%)\end{array}$ & $\begin{array}{c}52 \\
(25.8 \%)\end{array}$ & $\begin{array}{c}59 \\
(29.8 \%)\end{array}$ & $\begin{array}{c}12 \\
(6.1 \%)\end{array}$ & $\begin{array}{c}75 \\
(37.5 \%)\end{array}$ & $\begin{array}{c}41 \\
(20.5 \%)\end{array}$ \\
\hline Neutral & $\begin{array}{c}123 \\
(62.7 \%)\end{array}$ & $\begin{array}{c}121 \\
(61.7 \%)\end{array}$ & $88(43.6 \%)$ & $\begin{array}{c}72 \\
(35.6 \%)\end{array}$ & $\begin{array}{c}122 \\
(61.6 \%)\end{array}$ & $\begin{array}{c}112 \\
(56.5 \%)\end{array}$ & $\begin{array}{c}89 \\
(44.5 \%)\end{array}$ & $\begin{array}{c}89 \\
(44.5 \%)\end{array}$ \\
\hline Positive & $\begin{array}{c}12 \\
(6.1 \%)\end{array}$ & $\begin{array}{c}74 \\
(37.7 \%)\end{array}$ & $41(20.3 \%)$ & $\begin{array}{c}78 \\
(38.6 \%)\end{array}$ & $\begin{array}{c}17 \\
(8.6 \%)\end{array}$ & $\begin{array}{c}74 \\
(37.4 \%)\end{array}$ & $\begin{array}{c}36 \\
(18 \%)\end{array}$ & $\begin{array}{c}70 \\
(35 \%)\end{array}$ \\
\hline
\end{tabular}

Source: Author's own research.

In the context of content type (see Table 4), Russian media outlets focused more on the political and economic cases of the trade war. However, the economic analyses and reports became more popular during the second, active, research 
period. The social content was more widespread among the commercial and new media articles, which focused less on the official events connected with state authorities. Later the media started to consider the conflict from the economic perspective and set aside the political orientation to depict the crisis in a more balanced way.

Table 4. Russian media's type of content concerning the Sino-

American Trade War during the 1st period (20.01.2017-22.01.2018) and the 2nd period of research (22.01.2018-26.09.2019)

\begin{tabular}{|c|c|c|c|c|c|c|c|c|}
\hline & \multicolumn{2}{|c|}{$\begin{array}{c}\text { Federal }(\mathrm{N}=214) \\
\text { Rossiyskaya } \\
\text { gazeta }(\mathrm{n}=102) \\
\text { Ria Novosti }(\mathrm{n}=112)\end{array}$} & \multicolumn{2}{|c|}{$\begin{array}{l}\text { Commercial }(\mathrm{N}=217) \\
\text { Kommersant }(\mathrm{n}=113) \\
\text { Lenta.ru }(\mathrm{n}=104)\end{array}$} & \multicolumn{2}{|c|}{$\begin{array}{c}\text { Traditional }(\mathrm{N}=215) \\
\text { Rossiyskaya } \\
\text { gazeta }(\mathrm{n}=102) \\
\text { Kommersant }(\mathrm{n}=113)\end{array}$} & \multicolumn{2}{|c|}{$\begin{array}{l}\text { New media }(N=216) \\
\text { Ria Novosti }(n=112) \\
\text { Lenta.ru }(n=104)\end{array}$} \\
\hline & $\begin{array}{l}\text { First } \\
\text { period } \\
(n=18)\end{array}$ & $\begin{array}{l}\text { Second } \\
\text { period } \\
(n=196)\end{array}$ & $\begin{array}{l}\text { First } \\
\text { period } \\
(n=15)\end{array}$ & $\begin{array}{l}\text { Second } \\
\text { period } \\
(n=201)\end{array}$ & $\begin{array}{l}\text { First } \\
\text { period } \\
(\mathbf{n}=17)\end{array}$ & $\begin{array}{l}\text { Second } \\
\text { period } \\
(n=198)\end{array}$ & $\begin{array}{l}\text { First } \\
\text { period } \\
(n=16)\end{array}$ & $\begin{array}{l}\text { Second } \\
\text { period } \\
(n=200)\end{array}$ \\
\hline Political & $\begin{array}{c}8 \\
(44.4 \%)\end{array}$ & $92(46.9 \%)$ & $\begin{array}{c}9 \\
(60 \%)\end{array}$ & $\begin{array}{c}63 \\
(31.2 \%)\end{array}$ & $\begin{array}{c}11 \\
(64.7 \%)\end{array}$ & $\begin{array}{c}73 \\
(36.9 \%)\end{array}$ & $\begin{array}{c}6 \\
(37.6 \%)\end{array}$ & $\begin{array}{c}82 \\
(41 \%)\end{array}$ \\
\hline Economic & $\begin{array}{c}7 \\
(38.9 \%)\end{array}$ & $\begin{array}{c}95 \\
(48.5 \%)\end{array}$ & $\begin{array}{c}5 \\
(33.3 \%)\end{array}$ & $\begin{array}{c}111 \\
(54.9 \%)\end{array}$ & $\begin{array}{c}5 \\
(29.4 \%)\end{array}$ & $\begin{array}{c}115 \\
(58.1 \%)\end{array}$ & $\begin{array}{c}7 \\
(43.7 \%)\end{array}$ & $\begin{array}{c}91 \\
(45.5 \%)\end{array}$ \\
\hline Social & $\begin{array}{c}3 \\
(16.7 \%)\end{array}$ & $\begin{array}{c}9 \\
(4.6 \%)\end{array}$ & $\begin{array}{c}1 \\
(6.7 \%)\end{array}$ & 28 (13.9\%) & $\begin{array}{c}1 \\
(5.9 \%)\end{array}$ & $\begin{array}{c}10 \\
(5 \%)\end{array}$ & $\begin{array}{c}3 \\
(18.7 \%)\end{array}$ & $\begin{array}{c}27 \\
(13.5 \%)\end{array}$ \\
\hline
\end{tabular}

Source: Author's own research

The quantity of articles increased on a daily basis as a result of the intensification of the trade war. This in turn caused the quality and length of the articles decrease as evident in the replacing of the comprehensive analytical reports of the first period being replaced by short news articles describing each event during the active phase of trade war. Indeed, the length of the articles dropped by $34 \%$. However, the biggest decrease of the articles' length occurred among the commercial media outlets, which have intensified the frequency of articles, but reduced the number words at the same time by $49.9 \%$, while the federal media have decreased the length of articles by $12.3 \%$ (see Table 5 ). 
Table 5. Russian media's change in length of articles (word counts) concerning the Sino-American trade war during the 1st period (20.01.2017-

22.01.2018) and the $2 \mathrm{nd}$ period of research (22.01.2018-26.09.2019)

\begin{tabular}{|c|c|c|c|c|c|c|c|c|}
\hline & \multicolumn{2}{|c|}{$\begin{array}{c}\text { Federal }(\mathrm{N}=214) \\
\text { Rossiyskaya } \\
\text { gazeta }(\mathrm{n}=102) \\
\text { Ria Novosti }(\mathrm{n}=112)\end{array}$} & \multicolumn{2}{|c|}{$\begin{array}{c}\text { Commercial }(\mathrm{N}=217) \\
\text { Kommersant }(\mathrm{n}=113) \\
\text { Lenta.ru }(\mathrm{n}=104)\end{array}$} & \multicolumn{2}{|c|}{$\begin{array}{c}\text { Traditional }(\mathrm{N}=215) \\
\text { Rossiyskaya } \\
\text { gazeta }(\mathrm{n}=102) \\
\text { Kommersant }(\mathrm{n}=113)\end{array}$} & \multicolumn{2}{|c|}{$\begin{array}{c}\text { New media }(N=216) \\
\text { Ria Novosti }(n=112) \\
\text { Lenta.ru }(n=104)\end{array}$} \\
\hline & $\begin{array}{c}\text { First } \\
\text { period }\end{array}$ & $\begin{array}{l}\text { Second } \\
\text { period }\end{array}$ & $\begin{array}{l}\text { First } \\
\text { period }\end{array}$ & $\begin{array}{l}\text { Second } \\
\text { period }\end{array}$ & $\begin{array}{c}\text { First } \\
\text { period }\end{array}$ & $\begin{array}{l}\text { Second } \\
\text { period }\end{array}$ & $\begin{array}{c}\text { First } \\
\text { period }\end{array}$ & $\begin{array}{l}\text { Second } \\
\text { period }\end{array}$ \\
\hline $\begin{array}{l}\text { Average } \\
\text { word } \\
\text { count } \\
\text { of articles }\end{array}$ & 409.33 & 359.05 & 575.53 & 288.38 & 592.17 & 408.45 & 370.87 & 239.19 \\
\hline
\end{tabular}

Source: Author's own research

The media outlets did not change the topical focus of the articles from the first to the second period. The frequency of the keywords during the first period were: China (189), Trump (86), USA (84), Russia (44), War (23), Trade (20), Xi Jinping (9), Conflict (4) (see Picture 1). The word cloud shows the articles focused predominantly on international affairs and the political leaders and analyzed the state of affairs between the two sides. The position of USA president had more significance than any quotes from China's leader, which was connected with the provocative image of Trump that was more attractive for the media outlets in both negative and positive ways.

Picture 1. Russian media's word cloud concerning the Sino-American trade war during the 1st period of research (20.01.2017-22.01.2018)

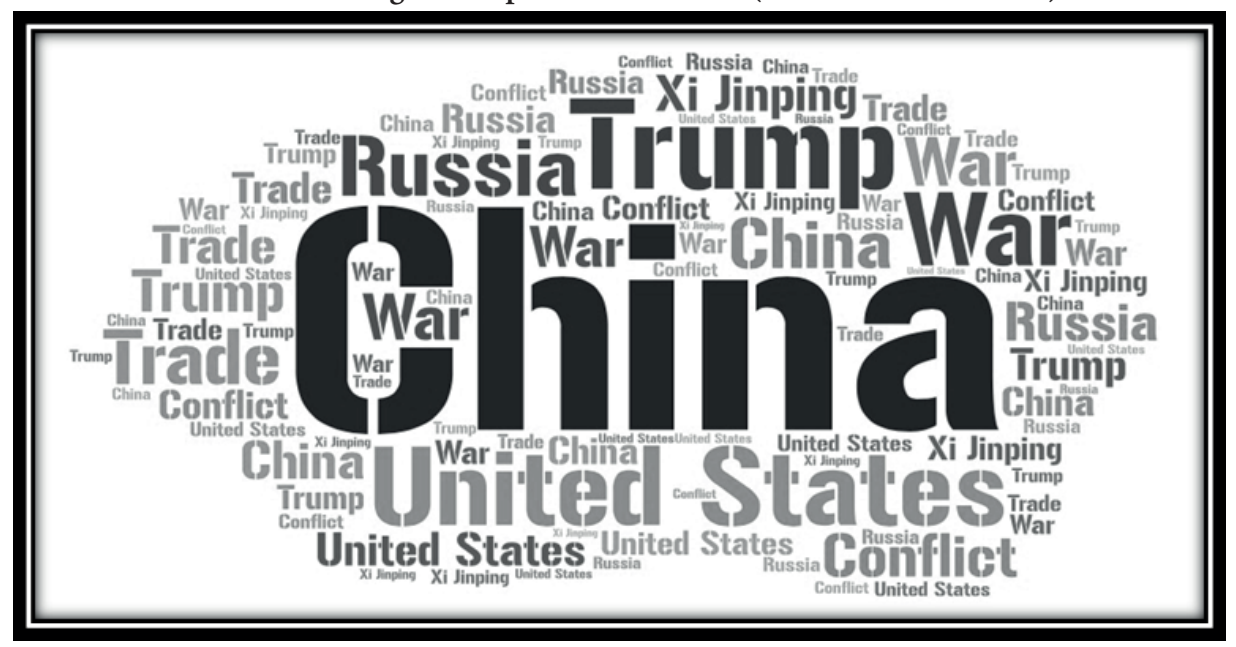

Source: Author's own research 
During the active phase (the 2nd period) the focus of the articles remained similar and covered the trade war emphasizing the position of China, and the negative rhetoric connected to the war frames were used more frequently. The intensification of the war frames could be also traced considering some of the news articles headlines, such as "United States prepare the new attack in trade war with China" (Lenta.ru, 22.05.2019), "China found a new weapon in a trade war with the United States" (Lenta.ru, 14.05.2019), "Trump changed his mind again and attacked in the trade war with China" (Lenta.ru, 11.05.2019). The peaceful and non-conflictual frames such as "Economy" and "Trade" and the opinion of countries' leaders "Trump" and "Xi Jinping" are less important in the overall media representation of trade war. The frequency of the keywords active phase were: China (987), War (656), United States (503), Russia (448), Trade (402), Trump (309), Conflict (251), Economy (220), Xi Jinping (55) (see Picture 2).

Picture 2. Russian media's word cloud concerning the Sino-American

trade war during the 2 nd period of research (22.01.2018-26.09.2019)

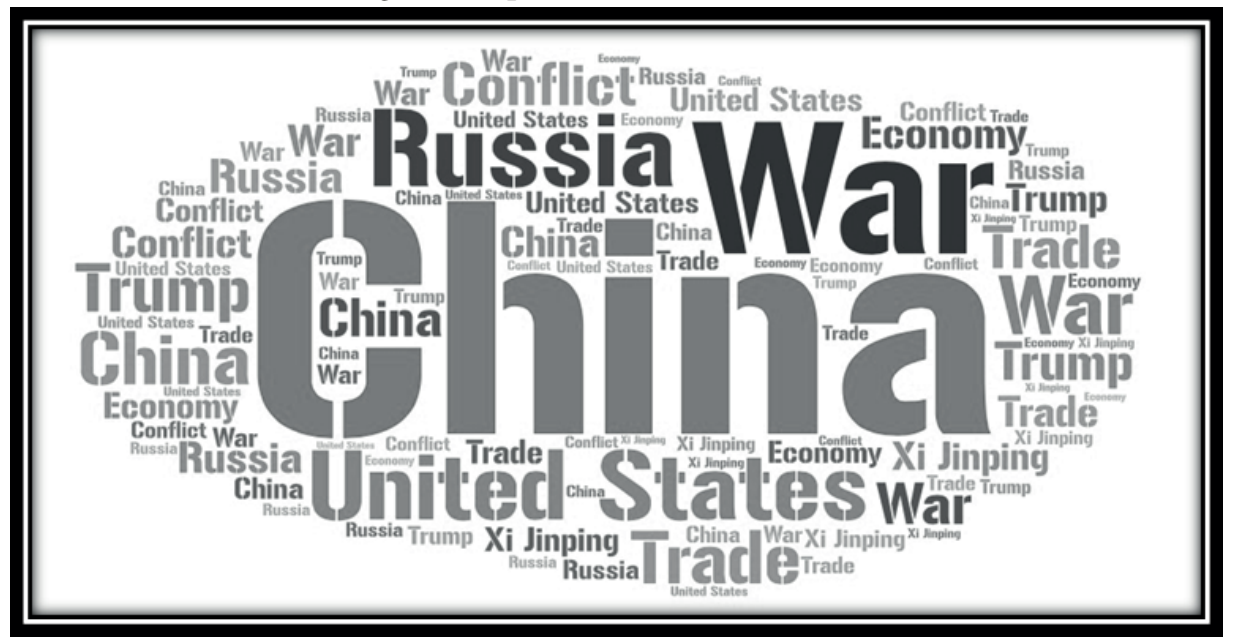

Source: Author's own research

The analysis of the basic framing categories showed the coverage of trade war became one of the most important on the economic agenda among Russian media outlets. The focus on the political nature of crisis, peculiar to the pre-war coverage, began decline and was replaced by the economic agenda. Thus, the predominant attitude towards the two sides remained neutral among all types of media with the focus on China and position of that nation's authorities. Furthermore, with rising importance of the rising understanding of the trade conflict as the "economic war" between two superpowers and its significance for Russia as one of the core countries a second focus was how this crisis affected Russia's business elites. It was during this period the number of articles increased corresponding 
with a decline in the overall length of articles (see Table 4). Therefore, the relevance of trade war between China and USA increased for the Russia's economy and thus for Russia's media, which prompted further analysis.

\section{THE WAR AND PEACE FRAMES OF THE TRADE WAR COVERAGE}

This part reflects the analysis of trade war's coverage using the four peace or conflict binaries (see Galtung's 1989 categories). The first binary refers to the partisan/non-partisan types of content, which showed the degree of bias in the articles and the supported the conflicting sides of the trade war. So, the vectors of coverage among most of the media outlets remained the same throughout the studied period. The federal media were more inclined to publish non-partisan content to present a neutral position in the articles, whereas the commercial media outlets had deeper links to the war frame and published partisan content. The same tendency is peculiar to both of the analysis periods of the trade war.

Comparing the traditional and new media, the former is more regulated by the government and focus on the federal position, which is why the content more non-partisan. However, the trend among the new media has changed over the time: non-bias peacemaking articles have become more partisan (bias) content, which is related to the war frame. This change could be connected with the specifics of new media companies, which are struggling to gain more viewers on their web pages and adopting the same principles of functioning as commercial media: sensationalism and exaggeration of facts (see Table 6).

Table 6. Russian media's partisan and non-partisan content concerning the Sino-American trade war during the 1st period (20.01.2017-

22.01.2018) and the 2 nd period of Research (22.01.2018-26.09.2019)

\begin{tabular}{|c|c|c|c|c|c|c|c|c|}
\hline & \multicolumn{2}{|c|}{$\begin{array}{c}\text { Federal }(\mathrm{N}=214) \\
\text { Rossiyskaya } \\
\text { gazeta }(\mathrm{n}=102) \\
\text { Ria Novosti }(\mathrm{n}=112)\end{array}$} & \multicolumn{2}{|c|}{$\begin{array}{l}\text { Commercial }(\mathrm{N}=217) \\
\text { Kommersant }(\mathrm{n}=113) \\
\text { Lenta.ru }(\mathrm{n}=104)\end{array}$} & \multicolumn{2}{|c|}{$\begin{array}{l}\text { Traditional }(\mathrm{N}=215) \\
\text { Rossiyskaya } \\
\text { gazeta }(\mathrm{n}=102) \\
\text { Kommersant }(\mathrm{n}=113)\end{array}$} & \multicolumn{2}{|c|}{$\begin{array}{c}\text { New media }(\mathrm{N}=216) \\
\text { Ria Novosti }(\mathrm{n}=112) \\
\text { Lenta.ru }(\mathrm{n}=104)\end{array}$} \\
\hline & $\begin{array}{l}\text { First } \\
\text { period } \\
(\mathrm{n}=18)\end{array}$ & $\begin{array}{l}\text { Second } \\
\text { period } \\
(n=196)\end{array}$ & $\begin{array}{l}\text { First } \\
\text { period } \\
(\mathrm{n}=15)\end{array}$ & $\begin{array}{l}\text { Second } \\
\text { period } \\
(n=202)\end{array}$ & $\begin{array}{l}\text { First } \\
\text { period } \\
(\mathrm{n}=17)\end{array}$ & $\begin{array}{l}\text { Second } \\
\text { period } \\
(n=198)\end{array}$ & $\begin{array}{l}\text { First } \\
\text { period } \\
(\mathrm{n}=16)\end{array}$ & $\begin{array}{l}\text { Second } \\
\text { period } \\
(n=200)\end{array}$ \\
\hline Partisan & $\begin{array}{c}6 \\
(33.3 \%)\end{array}$ & $\begin{array}{c}76 \\
(38.7 \%)\end{array}$ & $\begin{array}{c}8 \\
(53.3 \%)\end{array}$ & $\begin{array}{c}116 \\
(57.4 \%)\end{array}$ & $\begin{array}{c}7 \\
(41.2 \%)\end{array}$ & $\begin{array}{c}83 \\
(41.9 \%)\end{array}$ & $\begin{array}{c}7 \\
(43.75 \%)\end{array}$ & $\begin{array}{c}109 \\
(54.5 \%)\end{array}$ \\
\hline Non-partisan & $\begin{array}{c}12 \\
(66.7 \%)\end{array}$ & $\begin{array}{c}120 \\
(61.3 \%)\end{array}$ & $\begin{array}{c}7 \\
(46.7 \%)\end{array}$ & $\begin{array}{c}86 \\
(42.6 \%)\end{array}$ & $\begin{array}{c}10 \\
(58.8 \%)\end{array}$ & $\begin{array}{c}115 \\
(58.1 \%)\end{array}$ & $\begin{array}{c}9 \\
(56.25 \%)\end{array}$ & $\begin{array}{c}91 \\
(45.5 \%)\end{array}$ \\
\hline
\end{tabular}

Source: Author's own research

In the context of "Elite-oriented and people-oriented content", most Russian media outlets focused only on the top-ranked personalities and did not cover the events in a comprehensive way affecting the life of common people. However, comparing the federal and commercial media outlets, the most extreme application 
of elite-oriented content was identified among the federal mass media, which predominantly focused on individual personalities favorable to cover (Lozovskiy, 2011).

Therefore, it is important to notice that the obtained data set depicts the opposite tendency with the traditional mass media dominated by war frames and new media outlets - by peace frames of trade war coverage. One explanation is that historical importance of printed press as the source of national official news and political information focused on highly ranked personalities. So, with the growth of the importance of the conflict for the Russian political agenda, the coverage by traditional media outlets became even more elite-oriented during the active phase. At the same time, the commercial and new media predominantly followed the influence of the free market and commercial orientation of publishing content and focused on improving their ratings and popularity among readers. Thus, the content is related to the life of common people and provides different cases to depict the trade war. Moreover, the new media companies were less limited within the state policy towards the trade war and are the most balanced in this category by depicting different angles of the conflict especially during its active phase (see Table 7).

Table 7. Russian media's elite-oriented and people-oriented content concerning the Sino-American trade war during the 1st period (20.01.2017-

22.01.2018) and the 2 nd period of Research (22.01.2018-26.09.2019)

\begin{tabular}{|c|c|c|c|c|c|c|c|c|}
\hline & \multicolumn{2}{|c|}{$\begin{array}{c}\text { Federal }(\mathrm{N}=214) \\
\text { Rossiyskaya } \\
\text { gazeta }(\mathrm{n}=102) \\
\text { Ria Novosti }(\mathrm{n}=112)\end{array}$} & \multicolumn{2}{|c|}{$\begin{array}{l}\text { Commercial }(\mathrm{N}=217) \\
\text { Kommersant }(\mathrm{n}=113) \\
\text { Lenta.ru }(\mathrm{n}=104)\end{array}$} & \multicolumn{2}{|c|}{$\begin{array}{c}\text { Traditional } \\
(\mathrm{N}=215) \\
\text { Rossiyskaya } \\
\text { gazeta }(\mathrm{n}=102) \\
\text { Kommersant } \\
(\mathrm{n}=113)\end{array}$} & \multicolumn{2}{|c|}{$\begin{array}{c}\text { New media }(N=216) \\
\text { Ria Novosti }(n=112) \\
\text { Lenta.ru }(n=104)\end{array}$} \\
\hline & $\begin{array}{l}\text { First } \\
\text { period } \\
(n=18)\end{array}$ & $\begin{array}{l}\text { Second } \\
\text { period } \\
(n=196)\end{array}$ & $\begin{array}{l}\text { First } \\
\text { period } \\
(n=15)\end{array}$ & $\begin{array}{l}\text { Second } \\
\text { period } \\
(n=202)\end{array}$ & $\begin{array}{l}\text { First } \\
\text { period } \\
(\mathrm{n}=17)\end{array}$ & $\begin{array}{l}\text { Second } \\
\text { period } \\
(n=198)\end{array}$ & $\begin{array}{c}\text { First } \\
\text { period } \\
(n=16)\end{array}$ & $\begin{array}{l}\text { Second } \\
\text { period } \\
(n=200)\end{array}$ \\
\hline $\begin{array}{c}\text { Elite- } \\
\text { oriented }\end{array}$ & $\begin{array}{c}14 \\
(77.8 \%)\end{array}$ & $\begin{array}{c}132 \\
(67.4 \%)\end{array}$ & $\begin{array}{c}6 \\
(40 \%)\end{array}$ & $\begin{array}{c}120 \\
(59.4 \%)\end{array}$ & $\begin{array}{c}10 \\
(58.8 \%)\end{array}$ & $\begin{array}{c}148 \\
(74.8 \%)\end{array}$ & $\begin{array}{c}10 \\
(62.5 \%)\end{array}$ & $\begin{array}{c}104 \\
(52 \%)\end{array}$ \\
\hline $\begin{array}{l}\text { People- } \\
\text { oriented }\end{array}$ & $\begin{array}{c}4 \\
(22.2 \%)\end{array}$ & $\begin{array}{c}64 \\
(32.6 \%)\end{array}$ & $\begin{array}{c}9 \\
(60 \%)\end{array}$ & $\begin{array}{c}82 \\
(40.6 \%)\end{array}$ & $\begin{array}{c}7 \\
(41.2 \%)\end{array}$ & $\begin{array}{c}50 \\
(25.2 \%)\end{array}$ & $6(37.5 \%)$ & $\begin{array}{c}96 \\
(48 \%)\end{array}$ \\
\hline
\end{tabular}

Source: Author's own research

According to the data analysis, the federal and traditional media outlets related to the more balanced and peacemaking kinds of mass media, however the commercial and new media outlets expressed their attitude to the issue in more aggressive and drastic ways. The main reason for this tendency relates to the specifics of Russia's media market, which is more controlled in terms of federal and traditional media. Whereas the commercial and new media are freer to express their attitude as opposed to the federal position, which remained more neutral at the moment of data analysis. So, the commercial and new media 
companies are less self-limiting themselves and express their attitude about the countries in more direct and sharp ways. That is why the commercial media outlets are most highly ranked in the context of agitated content (see Table 8).

Table 8. Russian media's emotional level of content concerning the Sino-

American trade war during the 1st period (20.01.2017-22.01.2018) and the 2nd period of Research (22.01.2018-26.09.2019)

\begin{tabular}{|c|c|c|c|c|c|c|c|c|}
\hline & \multicolumn{2}{|c|}{$\begin{array}{c}\text { Federal }(\mathrm{N}=214) \\
\text { Rossiyskaya } \\
\text { gazeta }(\mathrm{n}=102) \\
\text { Ria Novosti }(\mathrm{n}=112)\end{array}$} & \multicolumn{2}{|c|}{$\begin{array}{l}\text { Commercial }(\mathrm{N}=217) \\
\text { Kommersant }(\mathrm{n}=113) \\
\text { Lenta.ru }(\mathrm{n}=104)\end{array}$} & \multicolumn{2}{|c|}{$\begin{array}{c}\text { Traditional }(\mathrm{N}=215) \\
\text { Rossiyskaya } \\
\text { gazeta }(\mathrm{n}=102) \\
\text { Kommersant }(\mathrm{n}=113)\end{array}$} & \multicolumn{2}{|c|}{$\begin{array}{c}\text { New media }(\mathrm{N}=216) \\
\text { Ria Novosti }(\mathrm{n}=112) \\
\text { Lenta.ru }(\mathrm{n}=104)\end{array}$} \\
\hline & $\begin{array}{l}\text { First } \\
\text { period } \\
(n=18)\end{array}$ & $\begin{array}{l}\text { Second } \\
\text { period } \\
(n=196)\end{array}$ & $\begin{array}{l}\text { First } \\
\text { period } \\
(n=15)\end{array}$ & $\begin{array}{l}\text { Second } \\
\text { period } \\
(n=202)\end{array}$ & $\begin{array}{l}\text { First } \\
\text { period } \\
(n=17)\end{array}$ & $\begin{array}{l}\text { Second } \\
\text { period } \\
(n=198)\end{array}$ & $\begin{array}{c}\text { First } \\
\text { period } \\
(n=16)\end{array}$ & $\begin{array}{r}\text { Second } \\
\text { period } \\
(n=200)\end{array}$ \\
\hline $\begin{array}{c}\text { Average } \\
\text { index }\end{array}$ & 2.46 & 2.15 & 2.83 & 3.58 & 2.23 & 2.41 & 3.08 & 3.23 \\
\hline
\end{tabular}

Source: Author's own research

Finally, the traditional and new media companies are more diverse in terms of content labeling, so the traditional media have changed from the labeling of the content towards a more balanced depiction of trade war. This could be explained by the change of the state policy on the trade war, which was more neutral towards both sides during the active phase. This was the reason the media began to cover the crisis in a more balanced way. The closer interrelations between the federal position and the traditional media have been researched by other scholars and are mentioned in the literature review (Lozovskiy, 2011). So they follow a neutral vector and avoid labeling the key objects in the text. However, the commercial media have their own editorial policies and label the content mostly according to their own vision, which can contain the labeling (see Table 9).

Table 9. Russian media's dichotomization of good and bad and avoiding labeling in the content concerning the Sino-American trade war during the 1 st period (20.01.2017-22.01.2018) and the 2 nd period of research $(22.01 .2018-26.09 .2019)$

\begin{tabular}{|c|c|c|c|c|c|c|c|c|}
\hline & \multicolumn{2}{|c|}{$\begin{array}{c}\text { Federal }(\mathrm{N}=214) \\
\text { Rossiyskaya } \\
\text { gazeta }(\mathrm{n}=102) \\
\text { Ria Novosti }(\mathrm{n}=112)\end{array}$} & \multicolumn{2}{|c|}{$\begin{array}{l}\text { Commercial }(\mathrm{N}=217) \\
\text { Kommersant }(\mathrm{n}=113) \\
\text { Lenta.ru }(\mathrm{n}=104)\end{array}$} & \multicolumn{2}{|c|}{$\begin{array}{c}\text { Traditional }(\mathrm{N}=215) \\
\text { Rossiyskaya } \\
\text { gazeta }(\mathrm{n}=102) \\
\text { Kommersant }(\mathrm{n}=113)\end{array}$} & \multicolumn{2}{|c|}{$\begin{array}{c}\text { New media }(N=216) \\
\text { Ria Novosti }(n=112) \\
\text { Lenta.ru }(n=104)\end{array}$} \\
\hline & $\begin{array}{c}\text { First } \\
\text { period } \\
(n=18)\end{array}$ & $\begin{array}{l}\text { Second } \\
\text { period } \\
(\mathrm{n}=196)\end{array}$ & $\begin{array}{l}\text { First } \\
\text { period } \\
(n=15)\end{array}$ & $\begin{array}{l}\text { Second } \\
\text { period } \\
(n=202)\end{array}$ & $\begin{array}{l}\text { First } \\
\text { period } \\
(n=17)\end{array}$ & $\begin{array}{l}\text { Second } \\
\text { period } \\
(n=198)\end{array}$ & $\begin{array}{l}\text { First } \\
\text { period } \\
(\mathrm{n}=16)\end{array}$ & $\begin{array}{c}\text { Second } \\
\text { period } \\
(n=198)\end{array}$ \\
\hline $\begin{array}{l}\text { Dichotomizes } \\
\text { good and bad }\end{array}$ & $\begin{array}{c}7 \\
(38.9 \%)\end{array}$ & $\begin{array}{c}73 \\
(37.2 \%)\end{array}$ & $10(66.7 \%)$ & $\begin{array}{c}140 \\
(69.3 \%)\end{array}$ & $\begin{array}{c}9 \\
(52.9 \%)\end{array}$ & $\begin{array}{c}80 \\
(40.4 \%)\end{array}$ & $\begin{array}{c}8 \\
(50 \%)\end{array}$ & $\begin{array}{c}133 \\
(67.2 \%)\end{array}$ \\
\hline Avoid labeling & $11(61.1 \%)$ & $\begin{array}{c}123 \\
(62.8 \%)\end{array}$ & $\begin{array}{c}5 \\
(33.3 \%)\end{array}$ & $\begin{array}{c}62 \\
(30.7 \%)\end{array}$ & $\begin{array}{c}8 \\
(47.1 \%)\end{array}$ & $\begin{array}{c}118 \\
(59.6 \%)\end{array}$ & $\begin{array}{c}8 \\
(50 \%)\end{array}$ & $\begin{array}{c}65 \\
(32.8 \%)\end{array}$ \\
\hline
\end{tabular}

Source: Author's own research 


\section{CONCLUSIONS}

Findings of the study revealed that the type of media influences the dominant media frame: the federal and traditional media outlets refer mostly to peace journalism type. Federal media are linked to state ownership through media conglomerates, which either the government or affiliated business companies own, so their activity is more correlated with the official position of the Russian political establishment. At the same time, media law frames the traditional media outlets, which are also in the context of loss-making printed media enterprises dependent on state funding. This is the reason these publications lean towards the peace frame. Furthermore, these types of media are less implicated in the use of sensationalism. They also adhere to the federal rhetoric which is dominated by idea of a balance between the financial superpowers (Index of Safety, 2013).

By contrast, the commercial and especially the new media outlets lean more towards the war frame of journalism. One of the reasons can be the financial factor represented by sensationalism combined with a more aggressive rhetoric to attract larger audiences. Both commercial and new media have relatively higher freedom to disclose a position in opposition to the government. However, the new media depict the most extreme opinions due to the simplified process of news delivery and less strict legislation concerning the establishment and subsequent functioning of a digital media company. For this reason, new media outlets can function as more independent companies as they rely on their individual resources (Syundyukov, 2014).

Did the study satisfactorily answer the three research question (RQs)? The answer to (RQ1), that is "Does the dominant frame of the trade war coverage differ between Russia's state-owned media and its commercial counterpart?" lies in the analysis of federal and commercial media. The federal media outlets were more focused on the balanced position of the Russian state and presented less aggressive arguments and were, therefore, more related to the peace frame. By contrast, the commercial media presented both sides of the trade war and even expressed their points of view in a more agitated manner, so their content was more war journalism oriented.

The same trend is viable for answering (RQ2): "Does the dominant frame of the trade war coverage differ between the Russia's traditional (print and broadcast media) and the new media (digital)?" The traditional media outlets covered both sides in a more neutral way although they used balanced analytics with the focus on the Russian place in the trade war. Thus, the main frame is related to peace journalism. By contrast, the new media companies presented new perspectives on the two superpowers, which often differed from the government's position and even public opinion. In this way, new 'digital' media provided new vectors of the coverage of the trade war, in which aggressive war journalism dominated. 
To answer RQ3: "Does the dominant frame change during study period?" It is necessary to identify the trends of coverage within two data collection periods. Over the period of almost two years from January 2017 to September 2019, the study found the image of China became more positive, while the attitude towards USA became more neutral (this was a switch from being negative) in the active phase of the conflict. The overall frame changed from the importance of the political agenda to that of the economic sphere. The content of the commercial and new media outlets became more aggressive in reinforcing the assertive rhetoric, while the federal media tended to cover the events with a more peace journalism frame. This shows that study has proven the war and peace journalism tendencies described in the literature review (Nazmetdinova \& Lebedeva, 2018). The significance of trade war for Russian media agenda increased during the active (2nd) phase as manifest in the increased quantity of articles, which correlated with lower word counts in published articles.

Therefore, the data analysis has demonstrated the trend that Russia considers a trade war from position of observer with the strong influence of political and economic factors of relations with China and USA (Davydov, 2017). In this case, the federal media tended to provide a more neutral coverage of the events but demonstrated a positive attitude towards China and a negative one towards the USA.

The analysis of the headlines and the overall content also presented Russia as the core country pretending to be a superpower, which seeks benefits for its own economy and strives to have an impact on the conflicting sides. Due to Russia's historical partnership with China, the attitude of the media remained either neutral or positive, which also correlated with the position of the Russian state and its attempts to strengthen Sino-Russian cooperation. Therefore, the Russian media agenda could be considered to be dominated by political and financial elites, which consider any trade war as an economic crisis that can negatively affect the Russian economy, which operates as part of the USA dominated free market. So, the significance for Russia of a trade war can only increase with the passage of time.

\section{REFERENCES}

Ahmed, S., Cho, J., \& Jaidka, K. (2018). Framing social conflicts in news coverage and social media: A multicountry comparative study. International Communication Gazette, 81(4), 346-371. https:// doi.org/10.1177/1748048518775000.

Balakin, V. (2017). Potential of Russian-Chinese cooperation in countering new challenges from the United States. China in global and regional politics. History and modernity, 109-120.

Comscore. (2013). 2013 Europe Digital Future in Focus. Digital Report. 
Coombs, T. (1999). Ongoing crisis communication: Planning, managing and responding. Sage Publications. Davydov, A. (2017). USA-China-Russia: New “Triangle” Games. China in global and regional politics. History and modernity, 91-108.

Galtung, J. (1998). High Road, Low Road: charting the course for Peace Journalism. Track Two: Constructive Approaches to Community and Political Conflict, 7(4). https://hdl.handle.net/10520/EJC111753.

Gehlbach, S., \& Sonin, K. (2014). Government control of the media. Journal of Public Economics, 118, 163-171. https://dx.doi.org/10.2139/ssrn.1315882.

Freedom House. (2016). Nations in Transit: Europe and Eurasia Brace for Impact. https://freedomhouse. org/report/nations-transit.

Harrison, D. (2005, July 29). Beware the sting in the Dragon's Tail. Financial Times. https://www.ft.com/ content/8c2ed808-0042-11da-b57e-00000e2511c8.

Index of Safety. (2013). The confrontation between China and US in Asia: the consequences for Russia. http://www.pircenter.org/media/content/files/9/13478949060.pdf.

Kirshin, B. (2012). State and private mass media: specifics of informational policy. Chelyabinsk State University Bulletin, 5(259), 85-87. https://cyberleninka.ru/article/n/gosudarstvennye-i-chastnye-smi-osobennosti-informatsionnoy-politiki.

Kravets, I. (2016). United States Presidential Election 2016: coverage in Russian press. Mordovian State University Press. https://cyberleninka.ru/article/n/prezidentskie-vybory-v-ssha-2016-goda-po-materialam-rossiyskoy-pressy.

Lozovskiy, B. (2011). Who and how manipulates the journalists: manipulative technologies of influence on mass media. Ural University Press, 196-214. http://hdl.handle.net/10995/36027.

Medialogy. (2017). Federal Mass Media: 2017. https://www.mlg.ru/ratings.

Nazmetdinova, I., \& Lebedeva, S. (2018). "New Media" in modern media discourse. Chuvash State Pedagogical University Bulletin, 77-86. https://cyberleninka.ru/article/n/novye-smi-v-sovremennom-mediadiskurse.

Nicolas-Gavilan, M. (2018). Peace Journalism in Iberoamerica: Mexican and Spanish Newspaper Coverage of Conflict. Revista de Comunication, 17(1), 93-113. http://dx.doi.org/10.26441/RC17.1-2018-A5.

Park, J. (2003). Contrasts in the coverage of Korea and Japan by US television networks: A Frame Analysis. Gazette (Leiden, Netherlands), 65(2), 145-164. https://doi.org/10.1177/0016549203065002003.

Syundyukov, N. (2014). Internet Mass-media and Features of Their Functioning. Management Consulting, 12, 180-190. https://cyberleninka.ru/article/n/internet-smi-i-osobennosti-ih-funktsionirovaniya.

Troush, S.M. (2014). United States-China-Russia. Relations: spheres of interdependence and Russia's priorities. Comparative Politics, 1(14), 53-59. https://cyberleninka.ru/article/n/rossiya-mezhdu-kitaem-i-ssha-miroporyadok-briks-integratsiya-v-atr-1.

Vinogradov, A. (2013). Europe and Russia in global confrontation of United States and China. China in global and regional politics. History and modernity, 132-142. https://cyberleninka.ru/article/n/ evropa-i-rossiya-v-globalnom-protivostoyanii-ssha-i-kitaya.

Zeng, Ka. (2004). Trade Threats, Trade Wars. Bargaining, Retaliation, and American Coercive Diplomacy. University of Michigan Press. https://doi.org/10.3998/mpub.17690. 